JURNAL RESPIRASI

$J R$

Vol. 1 No. 1 Januari 2015

\title{
Terapi ARV pada Penderita Ko-Infeksi TB-HIV
}

\author{
Indana Eva Ajmala, Laksmi Wulandari
}

\begin{abstract}
$T B$ and HIV have a very close relationship since the development of AIDS. Through a significant reduction in cellular immunity, $H I V$ affects the pathogenesis of tuberculosis, thereby increasing the risk of TB in HIV co-infected individuals. In 2006, there were an estimated 9.2 million new TB cases worldwide, there were 710.00 in patients with HIV and 500,000 cases with MDR-TB. Sensitivity to TB associated with cytokine production by T lymphocytes (IFN gamma and TNF are like alpha). During HIV infection, IFN gamma production declined dramatically in line with the decrease in CD4 T lymphocytes This leads to an increased risk of developing reactivation or reinfection Mycobacterium tuberculosis. Clinical symptoms of pulmonary TB in people living with HIV are often non-specific. Clinical symptoms often found are fever and significant weight loss. The other symptoms usually associated with extrapulmonary TB. Antiretrovirals are drugs that inhibit HIV replication. The main priority in patients co-infected with TB-HIV is a start of TB therapy, followed by cotrimoxazole and ARV. ARV treatment recommendation on co-infection tuberculosis is starting ARV therapy to all people living with HIV with active TB, regardless of CD4 cell count. Antiretroviral therapy start as soon as possible after TB treatment can be tolerated, as soon as 2 weeks and no more than 8 weeks. Regimen set by WHO for first-line regimen containing two nucleoside reverse transcriptase inhibitors (NRTIs) plus one non-nucleoside reverse transcriptase inhibitors (NNRTIs). In the co-infection of TB-HIV nucleoside was elected WHO recommended Zidovudine (AZT) or tenofovir disoproxil fumarate (TDF), in combination with lamivudine (3TC) or emricitabine (FTC). For NNRTI, WHO recommends efavirenz (EFV) or nevirapine (NVP).
\end{abstract}

Key words: ARV Treatment, TB HIV

\section{PENDAHULUAN}

TB dan HIV mempunyai hubungan yang sangat erat sejak semakin berkembangnya penyakit AIDS. Di seluruh dunia, TB merupakan infeksi oportunistik yang paling umum pada individu dengan HIV positif, dan tetap menjadi penyebab kematian terbanyak pada penderita dengan AIDS. Infeksi HIV memberikan kontribusi yang signifikan terhadap peningkatan insidens TB di seluruh dunia. Melalui penurunan imunitas seluler yang signifikan, HIV memengaruhi patogenesis TB, sehingga meningkatkan risiko TB pada individu dengan koinfeksi HIV dan meningkatkan kejadian TB ekstrapulmoner dan manifestasi radiologi yang atipikal, yang dapat memperlambat waktu diagnosis. Walaupun TB pada individu dengan HIV positif dapat ditangani dan dicegah, insidensnya semakin meningkat pada negara berkembang yang menjadi daerah endemik infeksi HIV dan TB. Interaksi antara obat HIV dan TB, toksisitas obat yang tumpang tindih serta immune reconstitution inflammatory syndrome (IRIS) menambah kompleks penanganan ko-infeksi TB dan HIV. ${ }^{1}$
WHO memperkirakan terdapat lebih dari 14 juta orang yang terinfeksi TB. Pada tahun 2006, diperkirakan terdapat 9,2 juta TB kasus baru di seluruh dunia, 710.00 terdapat pada penderita dengan HIV dan 500.000 kasus dengan MDR-TB. Pada tahun 2006, diperkirakan 1,7 juta orang meninggal karena TB, dan 200.000 kasus terdapat pada penderita dengan koinfeksi HIV. Kasus TB terbanyak terdapat di Asia dan Afrika. Sepertiga TB kasus baru terjadi di Asia Selatan, tetapi perkiraan insidens per kapita tertinggi di Afrika. Total $40 \%$ penderita HIV di Asia meninggal karena koinfeksi TB. ${ }^{2}$

Di Indonesia, sejak tahun 1999 telah terjadi peningkatan jumlah penderita HIV pada kelompok orang berperilaku risiko tinggi tertular HIV yaitu para penjaja seks komersial dan penyalahguna NAPZA suntikan di beberapa provinsi seperti DKI Jakarta, Riau, Bali, Jawa Barat dan Jawa Timur sehingga provinsi tersebut tergolong sebagai daerah dengan tingkat epidemi terkonsentrasi (concentrated level of epidemic). Tanah Papua sudah memasuki tingkat epidemi meluas (generalized epidemic). ${ }^{3}$ Di Indonesia menurut data Kementerian Kesehatan RI hingga akhir Desember 
2010 secara kumulatif jumlah kasus AIDS yang dilaporkan berjumlah 24.131 kasus dengan infeksi penyerta terbanyak adalah TB yaitu sebesar 11.835 kasus $(49 \%){ }^{4}$

\section{HUBUNGAN ANTARA HIV DAN TB}

Kepekaan terhadap TB berhubungan dengan produksi sitokin oleh limfosit T (seperti IFN gamma dan TNF alfa). IFN gamma memegang peranan penting pada pertahanan imunologis terhadap mikroba. TB berkembang menjadi kasus laten ketika respons imun tidak cukup untuk membasmi total kuman Micobacterium tuberculosis. Karena HIV menghancurkan CD4 limfosit T dan makrofag, sel yang memegang peranan penting pada pertahanan antimikroba, penderita yang terinfeksi HIV lebih peka dari populasi umum terhadap reaktifasi infeksi laten Mycobacterium tuberculosis. ${ }^{2}$

Selama infeksi HIV, produksi IFN gamma menurun secara dramatis sejalan dengan penurunan CD4 limfosit T. Hal ini mengarah terhadap peningkatan risiko yang nyata berkembangnya reaktivasi atau reinfeksi Mycobacterium tuberculosis. Risiko berkembangnya TB setelah infeksi asimtomatik diperkirakan lebih dari $10 \%$ per tahun pada penderita yang terinfeksi HIV, dibandingkan 5-10\% seumur hidup pada penderita dengan HIV negatif. Jumlah CD4 $\mathrm{T}$ limfosit memengaruhi frekuensi dan ekspresi klinis TB aktif. $^{2}$

Dan sebaliknya, TB aktif juga bisa memengaruhi replikasi HIV. Sitokin proinflamasi yang diproduksi oleh tuberculosis granuloma (khususnya TNF alfa) dihubungkan dengan peningkatan HIV-RNA dan perjalanan infeksi HIV yang lebih cepat. ${ }^{2}$ Dari penelitian eksperimental didapatkan bahwa Mycobacterium tuberculosis meningkatkan replikasi HIV dan meningkatkan kepekaan terhadap infeksi viral pada level selular. Sejumlah penelitian restropektif menunjukkan perburukan survival pada penderita HIV dengan TB. ${ }^{5}$

\section{MANIFESTASI KLINIS}

Gejala utama penderita TB paru adalah batuk berdahak selama 2 minggu atau lebih. Di samping itu dapat juga diikuti dengan gejala tambahan yaitu dahak bercampur darah, berkeringat pada malam hari tanpa aktivitas, nafsu makan menurun, berat badan menurun, malaise dan badan terasa lemas. Gejala sesak napas dan nyeri dada dapat ditemukan bila terdapat komplikasi (efusi pleura, pneumotoraks dan pneumonia). ${ }^{4}$

Gejala klinis TB paru pada ODHA seringkali tidak spesifik. Gejala klinis yang sering ditemukan adalah demam dan penurunan berat badan yang signifikan (lebih dari $10 \%)$. Di samping itu, dapat ditemukan gejala lain terkait TB ekstraparu (TB pleura, TB perikard, TB milier, TB susunan saraf pusat dan TB abdomen) seperti diare terus menerus selama lebih dari satu bulan, pembesaran kelenjar limfe di leher, sesak napas dan lain-lain. ${ }^{4}$

\section{PENGOBATAN TB PADA KO-INFEKSI TB- HIV}

Pada penderita TB yang mendapat pengobatan, angka kematian pada penderita HIV positif lebih tinggi daripada penderita dengan HIV negatif. Kasus kematian lebih tinggi pada penderita HIV dengan TB paru dan ekstraparu BTA negatif, karena pada penderita ini sistem imunnya lebih tertekan daripada penderita degan BTA positif. Kasus kematian menurun pada penderita yang mendapat terapi ARV. Prioritas utama pada penderita dengan koinfeksi TB-HIV adalah memulai terapi TB, diikuti dengan kotrimoksazol dan ARV. ${ }^{6}$

a. Pengobatan TB pada ODHA yang belum dalam pengobatan ARV

Bila penderita belum dalam pengobatan ARV, pengobatan TB dapat segera dimulai. Jika penderita dalam pengobatan TB maka teruskan pengobatan TBnya sampai dapat ditoleransi (2-4 minggu) dan setelah itu diberi pengobatan ARV. Keputusan untuk memulai pengobatan ARV pada penderita dengan pengobatan TB sebaiknya dilakukan oleh dokter yang telah mendapat pelatihan tata laksana penderita TB-HIV. ${ }^{4}$

b. Pengobatan pada ODHA sedang dalam pengobatan ARV

Bila penderita sedang dalam pengobatan ARV, sebaiknya pengobatan TB dimulai minimal di RS yang petugasnya telah dilatih TB-HIV, untuk diatur rencana pengobatan TB bersama dengan pengobatan ARV. Hal ini penting karena ada kemungkinan masalah yang harus dipertimbangkan, antara lain interaksi obat (rifampisin dengan beberapa jenis obat ARV), gagal pengobatan ARV, IRIS atau perlu substitusi obat ARV. ${ }^{4}$

\section{PENGOBATAN KOTRIMOKSAZOL}

PENCEGAHAN

Beberapa infeksi oportunistik pada ODHA dapat dicegah dengan pemberian pengobatan profilaksis. Terdapat dua macam pengobatan pencegahan yaitu profilaksis primer dan profilaksis sekunder.

- Profilaksis primer adalah pemberian pengobatan pencegahan untuk mencegah suatu infeksi yang belum pernah diderita.

- Profilaksis sekunder adalah pemberian pengobatan pencegahan yang ditujukan untuk mencegah berulangnya suatu infeksi yang pernah diderita sebelumnya.

Berbagai penelitian telah membuktikan efektivitas PPK dalam menurunkan angka kematian dan kesakitan pada orang yang terinfeksi HIV. Hal tersebut dikaitkan dengan penurunan insidens infeksi PCP. ${ }^{4,6}$ 


\section{ANTIRETROVIRAL TERAPI}

Antiretroviral adalah obat yang menghambat replikasi HIV. ${ }^{7}$ Antiretroviral terapi tersedia sejak tahun 1996 dan menghasilkan penurunan progresif angka infeksi HIV menjadi AIDS dan angka mortalitas penderita AIDS pada negara berkembang. ${ }^{8}$ Tujuan terapi dengan ARV adalah menekan replikasi HIV secara maksimum, meningkatkan limfosit CD4 dan memperbaiki kualitas hidup penderita yang pada gilirannya akan dapat menurunkan morbiditas dan mortalitas. ${ }^{7}$

\section{Golongan obat antiretroviral}

Terdapat empat golongan utama obat antiretroviral, yaitu:

1. Penghambat masuknya virus ke dalam sel (Fusion inhibitor)

Obat ini mengganggu pengikatan fusi masuknya HIV-1 ke sel inang dengan menghalangi salah satu dari beberapa target. Bekerja dengan cara berikatan dengan subunit GP41 selubung glikoprotein virus sehingga fusi virus ke target sel dihambat. Contoh obat penghambat fusi ini adalah enfuvirtid (T-20) dan maraviroc (MVC). ${ }^{7}$

2. Reverse Transcriptase Inhibitor (RTI)

a. Analog nukleosida (NRTI)

NRTI diubah secara intraseluler dalam 3 tahap penambahan 3 gugus fosfat dan selanjutnya berkompetisi dengan natural nukleotida menghambat RT sehingga perubahan RNA menjadi DNA terhambat. Selain itu NRTI juga menghentikan pemanjangan DNA. ${ }^{7,8}$ Contohnya:
- analog thymin:zidovudin (ZDV/AZT) dan stavudin (d4T)

- analog cytosin: lamivudin (3TC) dan zalcitabin (ddC)

- analog adenin: didanosine (ddI)

- analog guanin: abacavir (ABC)

b. Analog nukleotida (NtRTI)

Mekanisme kerja NtRTI pada penghambatan replikasi HIV sama dengan NRTI tetapi hanya memerlukan 2 tahapan proses fosforilasi. Contohnya: analog adenosin monofosfat: tenofovir. ${ }^{7}$

c. Non nukleosida (NNRTI)

Bekerjanya tidak melalui tahapan fosforilasi intraseluler tetapi berikatan langsung dengan reseptor pada RT dan tidak berkompetisi dengan nukleotida natural. Aktivitas antiviral terhadap HIV-2 tidak kuat. Contohnya nevirapin (NVP) dan efavirenz $(\mathrm{EFV}){ }^{7,8}$

3. Protease inhibitor (PI)

Protease inhibitor berikatan secara reversibel dengan enzim protease yang mengkatalisa pembentukan protein yang dibutuhkan untuk proses akhir pematangan virus. Akibatnya virus yang terbentuk tidak masuk dan tidak mampu menginfeksi sel lain. PI adalah ARV yang paling potensial. Contohnya: saquinavir (SQV), indinavir (IDV) dan nelfinavir (NFV). ${ }^{7,8}$

4. Integrase inhibitor

Mekanisme kerjanya menghambat enzim integrase, yang bertanggung jawab untuk integrase DNA virus ke dalam DNA sel yang terinfeksi. Contohnya raltegra $(\mathrm{RGV})$ dan elvitegravir $(\mathrm{EGV})^{9}$

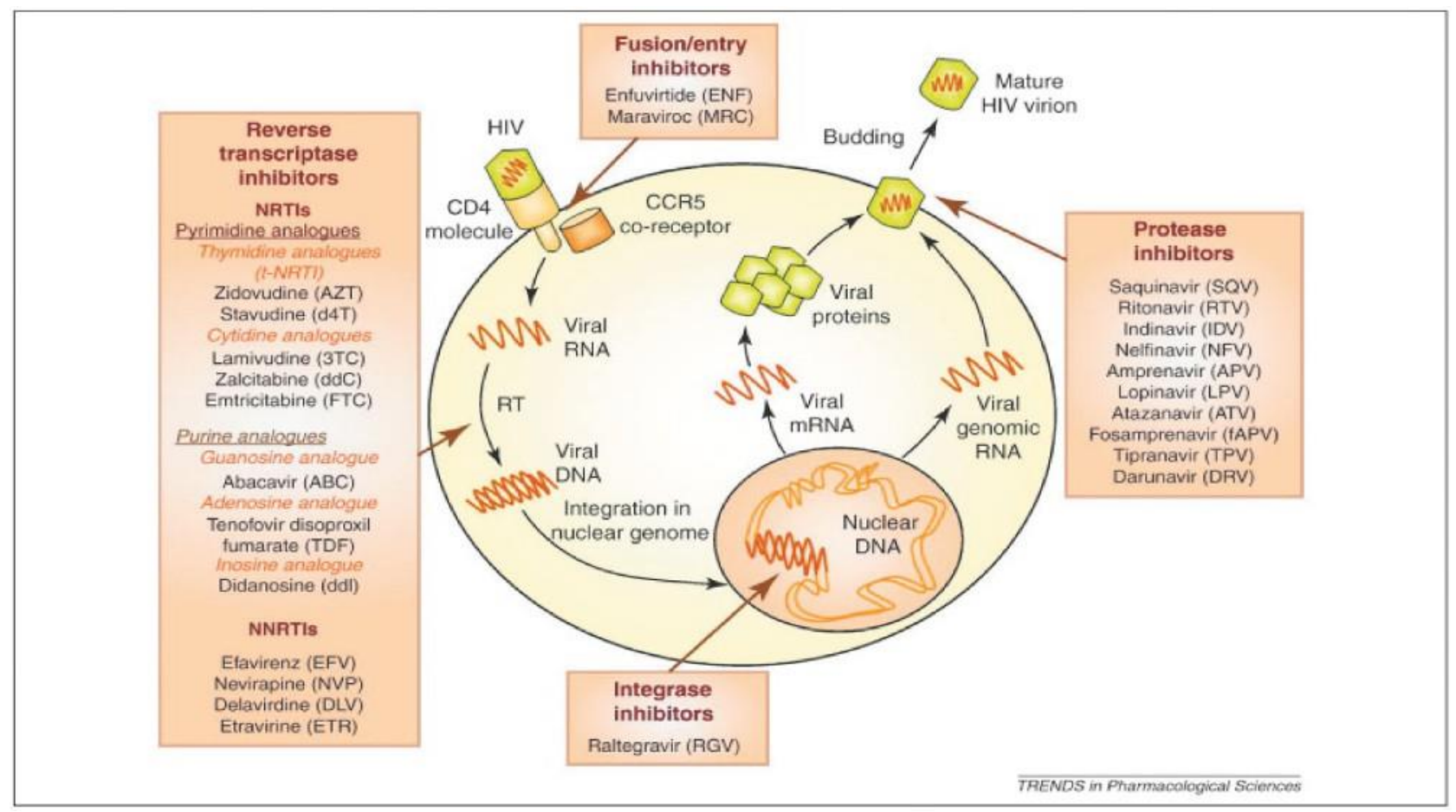

Gambar 1. Mekanisme kerja ARV ${ }^{7}$ 


\section{Saat memulai ARV}

Terapi ARV diberikan untuk semua ODHA yang menderita TB tanpa memandang jumlah CD4. Namun pengobatan TB tetap merupakan prioritas utama untuk penderita dan harus diberikan awal sebelum penderita mendapat ARV. Pengobatan ARV perlu dimulai meskipun penderita sedang dalam pengobatan TB. Perlu diingat, pengobatan TB di Indonesia selalu mengandung rifampisin sehingga penderita dalam pengobatan $\mathrm{TB}$ dan mendapat pengobatan ARV bisa mengalami masalah interaksi obat dan efek samping obat yang serupa sehingga memperberat efek samping obat. ${ }^{3,4}$

Rekomendasi terapi ARV pada Ko-Infeksi Tuberkulosis:

- Mulai terapi ARV pada semua ODHA dengan TB aktif, berapa pun jumlah CD4.

- Mulai terapi ARV sesegera mungkin setelah terapi TB dapat ditoleransi, secepatnya 2 minggu dan tidak lebih dari 8 minggu. ${ }^{3}$

Rekomendasi tersebut diharapkan dapat menurunkan angka kematian ko-infeksi TB-HIV, potensi menurunkan transmisi bila semua penderita HIV memulai terapi ARV lebih cepat, dan meningkatkan kualitas hidup, menurunkan kekambuhan TB dan meningkatkan manajemen TB pada penderita ko-infeksi TB-HIV. ${ }^{3}$

Penelitian CIPRA HT001 menunjukkan bahwa terapi ARV yang dimulai pada CD4 200-350 menurunkan risiko TB aktif sekitar 50\% dibandingkan dengan terapi yang menunggu sampai CD4 < 200. Hasil yang sama didapatkan pada penelitian HTPN 052, inisiasi ARV pada CD4 $\geq 350$ vs menunggu CD4 menurun $<250$, berhubungan dengan penurunan risiko aktif TB sebesar $47 \%$. Sebuah metaanalisis efek protektif ARV pada perkembangan TB menunjukkan penurunan risiko insidens TB sebesar 65\% pada semua jumlah CD4. Penurunan yang substansial terbesar $57 \%$ terlihat pada individu dengan jumlah CD4 $>350$ dan efek yang paling besar pada individu dengan jumlah CD4 $<200$. $^{1}$

\section{Panduan Obat yang Digunakan}

Pemerintah menetapkan paduan yang digunakan dalam pengobatan ARV berdasarkan pada 5 aspek yaitu: ${ }^{3}$

- Efektivitas

- Efek samping atau toksisitas

- Interaksi obat

- Kepatuhan

- Harga obat

Prinsip dalam pemberian ARV adalah: ${ }^{3}$

- Paduan obat ARV harus menggunakan 3 jenis obat yang terserap dan berada dalam dosis terapeutik.

Prinsip tersebut untuk menjamin efektivitas penggunaan obat.

- Membantu penderita agar patuh minum obat antara lain dengan mendekatkan akses pelayanan ARV.

- Menjaga kesinambungan ketersediaan obat ARV dengan menerapkan manajemen logistik yang baik
Paduan obat yang ditetapkan oleh WHO untuk lini pertama adalah regimen yang mengandung dua Nucleoside reverse transcriptase inhibitors (NRTI) ditambah dengan satu Non Nucleoside reverse transcriptase inhibitors (NNRTI). ${ }^{3,6}$

\section{NRTI + 1 NNRTI}

Terapi ARV diketahui dapat menurunkan laju TB sampai sebesar $90 \%$ pada tingkat individu dan sampai sekitar $60 \%$ pada tingkat populasi dan menurunkan rekurensi TB sebesar 50\%. Pada ko-infeksi TB-HIV NRTI terpilih yang direkomendasikan WHO adalah Zidovudine (AZT) atau tenofovir disoproxil fumarate (TDF), dikombinasi dengan lamivudine (3TC) atau emricitabine (FTC). Untuk NNRTI, WHO merekomendasikan efavirenz (EFV) atau nevirapine (NVP). ${ }^{3,6}$

\section{Pilihan NRTI}

Tidak ada interaksi mayor antara rifampisin atau rifabutin dengan lamivudine, emricitabine, tenofovir, abcavir, zidovudine atau didanosine. Stavudine tidak bisa diberikan karena peningkatan risiko neuropati perifer bersamaan dengan terapi TB.6,11 Paduan tripel NRTI hanya diberikan bila ada kontraindikasi atau tidak dapat mentoleransi NNRTI atau terjadi toksisitas. Paduan triple NRTI yang dapat diberikan adalah: AZT+ 3TC +TDF akan tetapi paduan triple NRTI tersebut kurang poten dibanding dengan paduan berbasis NNRTI. ${ }^{3}$

Tabel 1. Paduan lini pertama yang direkomendasikan pada orang dewasa yang belum pernah mendapat terapi ARV

\begin{tabular}{|l|l|l|}
\hline Populasi Target & \multicolumn{1}{|c|}{$\begin{array}{c}\text { Pilihan vang } \\
\text { direkomendasikan }\end{array}$} & \multicolumn{1}{c|}{ Catatan } \\
\hline Dewasa dan anak & $\begin{array}{l}\text { AZT atau TDF + 3TC } \\
\text { (atau FTC) + EFV atau } \\
\text { NVP }\end{array}$ & $\begin{array}{l}\text { Merupakan pilihan paduan yang sesual } \\
\text { untuk sebagian besar pasien } \\
\text { Gunakan FDC jika tersedia }\end{array}$ \\
\hline Perempuan hamil & $\begin{array}{l}\text { AZT + 3TC + EFV atau } \\
\text { NVP }\end{array}$ & $\begin{array}{l}\text { Tidak boleh menggunakan EFV pada } \\
\text { trimester pertama } \\
\text { TDF bisa merupakan pilinan }\end{array}$ \\
\hline Ko-infeksi HIVTTB & $\begin{array}{l}\text { AZT atau TDF + 3TC } \\
\text { (FTC) + EFV }\end{array}$ & $\begin{array}{l}\text { Mulai terapi ARV segera setelah terapi } \\
\text { TB dapat ditoleransi (antara 2 minggu } \\
\text { hingga 8 minggu) } \\
\text { Gunakan NVP atau triple NRTI bila EFV } \\
\text { tidak dapat digunakan }\end{array}$ \\
\hline $\begin{array}{l}\text { Ko-infeksi } \\
\text { HIV/Hepatitis B } \\
\text { kronik aktif }\end{array}$ & $\begin{array}{l}\text { TDF + 3TC (FTC) + EFV } \\
\text { atau NVP }\end{array}$ & $\begin{array}{l}\text { Pertimbangkan pemeriksaan HBSAg } \\
\text { terutama bila TDF merupakan paduan lini } \\
\text { pertama. Diperlukan penggunaan 2 ARV } \\
\text { yang memiliki aktivitas anti-HBV }\end{array}$ \\
\hline
\end{tabular}

Tabel 2. Terapi ARV untuk penderita koinfeksi TB-HIV

\begin{tabular}{|c|c|c|}
\hline CD4 & Paduan yang Dianjurkan & Keterangan \\
\hline $\begin{array}{l}\text { Berapapun } \\
\text { jumlah CD4 }\end{array}$ & $\begin{array}{l}\text { Mulai terapi TB. } \\
\text { Gunakan paduan yang mengandung EFV } \\
\text { (AZT atau TDF) + 3TC + EFV ( } 600 \\
\text { mg/hari). } \\
\text { Setelah OAT selesai maka bila perlu EFV } \\
\text { dapat diganti dengan NVP } \\
\text { Pada keadaan dimana paduan berbasis } \\
\text { NVP terpaksa digunakan bersamaan } \\
\text { dengan pengobatan TB maka NVP } \\
\text { diberikan tanpa lead-in dose (NVP } \\
\text { dberikan tiap } 12 \text { jam sejak awal terapi) }\end{array}$ & $\begin{array}{l}\text { Mulai terapi ARV segera } \\
\text { setelah terapi TB dapat } \\
\text { ditoleransi (antara } 2 \\
\text { minggu hingga } 8 \\
\text { minggu) }\end{array}$ \\
\hline $\begin{array}{l}\text { CD4 tidak } \\
\text { mungkin } \\
\text { diperiksa }\end{array}$ & Mulai terapi TB. & $\begin{array}{l}\text { Mulai terapi ARV segera } \\
\text { setelah terapi TB dapat } \\
\text { ditoleransi (antara } 2 \\
\text { minggu hingga } 8 \\
\text { minggu) }\end{array}$ \\
\hline
\end{tabular}




\section{Pilihan NNRTI}

EFV merupakan pilihan utama dibandingkan NVP, karena penurunan kadar dalam darah akibat interaksi dengan rifampisin adalah lebih kecil dan efek hepatotoksik yang lebih ringan. ${ }^{3}$ Dosis standar EFV adalah $600 \mathrm{mg} /$ hari. ${ }^{4}$

Kadar NVP juga menurun bila diberikan bersama rifampisin. Namun dianjurkan pemberian NVP tetap dengan dosis standar. Tetapi karena kemungkinan terdapatnya efek hepatotoksik, paduan berisi NVP hanya digunakan bila tidak ada alternatif lain terutama pada perempuan yang mendapat paduan OAT yang mengandung rifampisin dengan jumlah CD4 > 250/mm. ${ }^{3,4}$

Pada keadaan TB terdiagnosis atau muncul dalam 6 bulan sejak memulai terapi ARV lini pertama maupun lini kedua, maka perlu mempertimbangkan substitusi obat ARV karena berkaitan dengan interaksi obat TB khususnya Rifampisin dengan NNRTI dan PI. ${ }^{3}$

Pada penderita HIV yang sedang dalam pengobatan ARV yang kemudian menderita TB maka pilihan paduan pengobatan ARV adalah sebagai berikut: ${ }^{3,4}$

Bila terapi TB sudah lengkap dapat dipertimbangkan kembali untuk mengganti paduan ARV ke NVP kembali. $^{3}$

\section{Interaksi obat pada penatalaksanaan koinfeksi TB-HIV}

Penatalaksanaan TB dan HIV pada saat yang bersamaan menimbulkan interaksi obat antara rifampisin dengan ARV golongan NNRTI dan PI. Rifampisin menstimulasi aktivitas enzim hepar cytochrome P450, yang memetabolisme NNRTI dan PI. Hal ini mengakibatkan menurunnya kadar NNRTI dan PI dalam darah. NNRTI dan PI juga dapat menyebabkan peningkatan atau penghambatan enzim pada system yang sama, sehingga memengaruhi kadar rifampisin dalam darah. Interaksi obat-obat ini mengakibatkan

Tabel 3. Paduan ARV bagi ODHA yang kemudian muncul TB aktif

\begin{tabular}{|l|l|l|}
\hline Paduan ARV & $\begin{array}{l}\text { Paduan ARV } \\
\text { pada Saat TB } \\
\text { Muncul }\end{array}$ & Pilihan Terapi ARV \\
\hline Lini pertama & $2 \mathrm{NRTI}+\mathrm{EFV}$ & Teruskan dengan 2 NRTI + EFV \\
\cline { 2 - 3 } & 2 NRTI + NVP & $\begin{array}{l}\text { Ganti dengan EFV atau } \\
\text { Teruskan dengan 2 NRTI + NVP. Triple } \\
\text { NRRT dapat dipertimbangkan digunakan } \\
\text { selama 3 bulan jika NVP dan EFV tidak } \\
\text { dapat digunakan. }\end{array}$ \\
\hline Lini kedua & $2 \mathrm{NRTI}+$ PI/r & $\begin{array}{l}\text { Mengingat rifampisin tidak dapat digunakan } \\
\text { bersamaan dengan LPV/r, } \\
\text { dianjurkanmenggunakan paduan OAT } \\
\text { tanpa ritampisin. Jika ritampisin perlu } \\
\text { diberikan maka pilinan lain adalah } \\
\text { menggunakan gi LPV/r dengan dosis 800 } \\
\text { mg/200 mg dua kali sehari). Perlu evaluasi } \\
\text { fungsi hati ketat jika menggunakan } \\
\text { Rifampisin dan dosis ganda LPVIr }\end{array}$ \\
\hline
\end{tabular}

pengobatan ARV dan pengobatan TB menjadi tidak efektif, serta meningkatkan toksisitas obat. ${ }^{11,12}$

Efavirens adalah NNRTI dengan masa paruh yang lebih panjang dari nevirapine. Konsentrasi Efavirens di antara 1-4 mg/L dipilih untuk meyakinkan efikasi dan menurunkan risiko toksisitas obat. Obat ini merupakan obat yang biasa digunakan, dengan efek samping yang lebih sedikit dibandingkan dengan nevirapin, dan interaksi yang terbatas dengan rifampisin. Walaupun interaksi antara efavirens dan rifampisin tetap terjadi, tidak diperlukan peningkatan dosis efavirens pada individu Asia. ${ }^{13}$

\section{Efek Samping}

Pada penderita yang menerima pengobatan ko-infeksi TB-HIV, penanganan efek samping obat dijelaskan pada tabel $4:^{4}$

\section{KESIMPULAN}

TB dan HIV mempunyai hubungan yang sangat erat sejak semakin berkembangnya penyakit AIDS. Di seluruh dunia, TB merupakan infeksi oportunistik yang paling umum pada individu dengan HIV positif, dan tetap menjadi penyebab kematian terbanyak pada penderita dengan AIDS. Infeksi HIV memberikan kontribusi yang signifikan terhadap peningkatan insidens HIV di seluruh dunia.

Kepekaan terhadap TB berhubungan dengan produksi sitokin oleh limfosit $\mathrm{T}$ (seperti IFN gamma dan TNF alfa). Selama infeksi HIV, produksi IFN gamma menurun secara dramatis sejalan dengan penurunan CD4 limfosit T. Hal ini mengarah terhadap peningkatan risiko yang nyata berkembangnya reaktifasi atau reinfeksi Mycobacterium tuberculosis.

Gejala klinis TB paru pada ODHA seringkali tidak spesifik. Gejala klinis yang sering ditemukan adalah demam dan penurunan berat badan yang signifikan (lebih dari 10\%). Di samping itu, dapat ditemukan gejala lain terkait TB ekstra-paru.

Antiretroviral adalah obat yang menghambat replikasi HIV. Rekomendasi terapi ARV pada Ko-Infeksi Tuberkulosis adalah mulai terapi ARV pada semua ODHA dengan TB aktif, berapa pun jumlah CD4 dan sesegera mungkin setelah terapi TB dapat ditoleransi, secepatnya 2 minggu dan tidak lebih dari 8 minggu.

Pada ko-infeksi TB-HIV NRTI terpilih yang direkomendasikan WHO adalah Zidovudine (AZT) atau tenofovir disoproxil fumarate (TDF), dikombinasi dengan lamivudine (3TC) atau emricitabine (FTC). Untuk NNRTI, WHO merekomendasikan efavirenz (EFV) atau nevirapine (NVP). 
Tabel 4. Penanganan Efek Samping Obat

\begin{tabular}{ll}
\hline TANDA/GEJALA & TATALAKSANA \\
\hline Anoreksia, mual dan nyeri perut & Telan obat setelah makan. Jika panduan obat ARV mengandung ZDV, jelaskan pada \\
& penderita bahwa obat ini akan hilang sendiri. Atasi keluhan secara simtomatis. \\
& Tablet INH dapat diberikan malam sebelum tidur. \\
& Makanan yang dianjurkan adalah makanan lunak, porsi kecil dan frekuensianya sering. \\
& Beri analgetik, misalnya aspirin atau parasetamol \\
Nyeri sendi & Efek ini jelas dijumpai bilai INH diberi bersama ddI atau d4T, substitusi ddI atau d4T \\
Rasa kesemutan pada kaki & sesuai pedoman. Berikan tambahan tablet vitamin b6 (piridoksin) 100 mg/hari. Jika tidak \\
& berhasil, gunakan amitriptilin atau rujuk ke RS spesialistik \\
& Jelaskan pada penderita bahwa itu adalah warna obat, jadi tidak berbahaya \\
Kencing warna kemerahan/oranye & Beri analgetik (misalnya aspirin atau parasetamol). Periksa tanda-tanda meningitis. Bila \\
Sakit kepala & dalam pengobatan dengan ZDV atau EFV, jelaskan bahwa ini biasa terjadi dan biasanya \\
& hilang sendiri. Berikan EFV pada malam hari. Jika sakit kepala menetap lebih dari \\
& 2 minggu atau memburuk, penderita dirujuk
\end{tabular}

Diare

Beri oralit atau cairan pengganti dan ikuti petunjuk penanganan diare. Yakinkan pada penderita bahwa kalau disebabkan oleh obat ARV itu akan membaik setelah beberapa minggu. Pantau dalam 2 minggu, kalau belum membaik, penderita dirujuk

Kelelahan Pikirkan anemi terutama bila paduan obat mengandung ZDV. Periksa hemoglobin. Kelelahan biasanya berlangsung selama 4-6 minggu setelah ZDV dimulai. Jika berat atau berlanjut (lebih dari 4-6 minggu), penderita dirujuk.

Tegang, mimpi buruk Ini mungkin disebabkan oleh EFV. Lakukan konseling dan dukungan (biasanya efek samping berakhir kurang dari 3 minggu). Rujuk penderita jika depresi berat, usaha buuh diri atau psikosis. Masa sulit pertama biasanya dapat diatasi dengan amitriptilin pada malam hari.

Kuku kebiruan atau kehitaman Yakinkan penderita bahwa hal ini biasa terjadi pada pengobatan dengan AZT

Perubahan dalam distribusi lemak Diskusikan dengan penderita, apakah dia dapat menerima kenyataan ini, karena hal ini tidak bisa disembuhkan. Ini merupakan salah satu efek samping dari d4T. Oleh sebab itu, jika tidak ejadi efek samping setelah 2 tahun pengobatan d4T, lakukan substitusi d4T dengan TDF.

Gatal atau ruam kulit Jika menyeluruh atau mengelupas, stop obat TB dan obat ARV dan penderita dirujuk. Jika dalam pengobatan dengan

NVP, periksa dengan teliti: apakah lesinya kering (kemungkinan alergi) atau basah (kemungkinan Steven Johnson Syndrom). Mintalah pendapat ahli

Gangguan pendengaran/keseimbangan Hentikan streptomisin, kalau perlu rujuk ke unit DOTS Lakukan Ikterus pemeriksaan fungsi hati, hentikan OAT dan obat ARV. Mintalah pendapat ahli atau penderita dirujuk

Ikterus dan nyeri perut Hentikan OAT dan ARV dan periksa fungsi hati (bila tersedia sarana). Mintalah pendapat ahli atau penderita dirujuk. Nyeri perut mungkin karena pancreatitis disebabkan oleh ddl atau D4T

Muntah berulang Periksa penyebab muntah, lakukan pemeriksaan fungsi hati. Kalau terjdi hepatotoksik, hentikan OAT dan obat ARV, mintalah pendapat ahli atau penderita dirujuk.

Penglihatan berkurang Demam Hentikan etambutol, mintalah pendapat ahli atau dirujuk Periksa penyebab demam, mungkin karena efek samping obat, IO atau infeksi baru atau IRIS/SPI. Beri parasetamol dan mintalah pendapat ahli atau penderita dirujuk.

Pucat, anemi Ukur kadar hemoglobin atau singkirkan IO. Bila pucat sekali atau kadar $\mathrm{Hb}$ sangat rendah $(<8 \mathrm{gr} / \mathrm{dL} ;<7 \mathrm{gr} / \mathrm{dL}$ pada ibu hamil), penderita dirujuk (dan stop ZDV/diganti d4T)

\section{DAFTAR PUSTAKA}

1. Luetkemeyer A. Comprehensive, up-to-date information on HIV/ AIDS treatment, prevention, and policy, from the University of California San Francicsco. 2013. Available from: http://hivinsite. ucsf.edu/

2. Avihingsanon A, Hemachandra A, Lugt J van de. Antiretroviral therapy for HIV-associated tuberculosis. Asian Biomedicine Vol.3 No.1 2009; 73-87.

3. Kementerian Kesehatan Republik Indonesia Direktorat Jenderal Pengendalian Penyakit dan Penyehatan Lingkungan. Pedoman nasional tatalaksana klinis infeksi HIV dan terapi antiretroviral pada orang dewasa. 2012. Jakarta: Kementerian Kesehatan RI.

4. Kementerian Kesehatan Republik Indonesia Direktorat Jenderal Pengendalian Penyakit dan Penyehatan Lingkungan. Petunjuk teknis tatalaksana klinis ko-infeksi TB-HIV. 2013. Jakarta: Kementerian Kesehatan RI

5. Karakousis P, Chaisson R. Mycobacterial infections and HIV infection. In: Fishman A, Elias J, Fishman J, Grippi M, Senior R, Pack A. Fishman's pulmonary diseases and disorders. Fourth ed. 2008. New York: Mc Graw Hill. p 2487-98.

6. World health Organization. Treatment of tuberculosis guidelines. Fourth ed. 2010. Geneva: WHO Press. 
7. Direktorat Bina Farmasi Komunitas dan Klinik Ditjen Bina Kefarmasian dan Alat Kesehatan Departemen Kesehatan RI. Pedoman pelayanan kefarmasian untuk ODHA. 2006. Jakarta: Departemen Kesehatan RI.

8. Bourke SJ. Respiratory medicine. Sixth ed. 2003. United Kingdom: Blackwell Publishing.

9. Hoffmant et al. Antiretroviral therapy in HIV medicine. 2007.

10. Pozniak AL, Coyne KM, Miller RF, Lipman MCI, Freedman AR, Omerod LP, et al. British HIV association guidelines for the treatment of TB/HIV coinfection 2011.
11. TB/HIV Collaboration Disesase Control and Prevention Departemen Ghana Health Service. Guidelines for the clinical management of TB and HIV co-infection in Ghana. 2007.

12. A Working Group of the Office of AIDS Research Advisory Council (OARAC). Guidelines for the use of antiretroviral agents in HIV infected adults and adolescents. 2013. Available from: http://aidsinfo.nih.gov/guidelines

13. Lught J, Avihingsanon A. Clinical pharmacology and pharmacokinetics of antiretrovirals in Asia. Asian biomedicine Vol.3 No. 1 2009; 53-62. 